\title{
Serum-Positive and -Negative AQP4 Antibody NMO in Chinese Patients
}

\author{
Youming Long, Zhengqi Lu, Xueqiang $\mathrm{Hu}$
}

\begin{abstract}
Objective: To compare the clinical features of our sero-negative and sero-positive neuromyelitis optica (NMO) patients. Methods: Thirty-nine patients with NMO were recruited and analyzed retrospectively. Serum aquaporin 4 (AQP4) antibody status was determined by a cell-based assay. For the sero-negative patients, cerebrospinal fluid (CSF) and serum samples were re-tested using the cell-based assay and an indirect immunofluorescence assay. Results: By the cell-based assay, 30 patients (76.92\%, 30/39), were positive for AQP4 antibodies in serum and 37 patients $(94.9 \%, 37 / 39)$, had a CSF-positive antibody status. Seven NMO patients (17.9\%, 7/39) were sero-negative by the cell-based assay but demonstrated positive CSF results. By indirect immunofluorescence, the remaining two patients, who had no AQP4 antibodies in serum or CSF by the cell-based assay, were positive for IgG antibodies in serum, which selectively targeted the central nervous system microvessels, pia, subpia, Virchow-Robin space, kidney, and stomach. There were no significant differences between the sero-positive and sero-negative NMO groups among their demographic and clinical data. Conclusions: Repeating the test using a different assay or CSF is helpful to clarify whether sero-negative NMO patients do in fact carry AQP4 antibodies.
\end{abstract}

RÉSUMÉ: Séropositivité et séronégativité pour l'anticorps AQP4 chez des patients chinois atteints de NMO. Objectif : Le but de l'étude était de comparer les caractéristiques cliniques des patients atteints de neuromyélite optique (NMO) qui sont séropositifs et séronégatifs. Méthode : Trente-neuf patients atteints de NMO ont été recrutés et nous avons procédé à une analyse rétrospective de leurs données. Le dosage d'anticorps contre l'aquaporine 4 (AQP4) a été réalisé au moyen d'un test cellulaire. Chez les patients séronégatifs, des échantillons de liquide céphalo-rachidien (LCR) et de sérum ont été réanalysés par un test cellulaire et un test d'immunofluorescence indirecte. Résultats : Le test cellulaire a démontré la présence d'anticorps dirigés contre AQP4 dans le sérum chez 30 des 39 patients (76,92\%) et la présence d'anticorps dans le LCR chez 37 des 39 patients (94,9\%). Sept patients $(17,9 \%)$ étaient séronégatifs selon le test cellulaire ; cependant, le test fait sur le LCR était positif. Les deux autres patients qui n'avaient pas d'anticorps dirigés contre l'AQP4 dans le sérum ou le LCR selon le test cellulaire, étaient positifs pour des anticorps IgG dans le sérum par immunofluorescence indirecte ciblant sélectivement les microvaisseaux du système nerveux central, la pie-mère, la zone sous-pie-mérienne, l'espace de Virchow-Robin, le rein et l'estomac. Il n'y avait pas de différence significative entre les groupes NMO séropositifs et séronégatifs quant aux données démographiques et cliniques. Conclusions : Il est utile de répéter le test avec une méthode différente ou de le faire sur le LCR pour déterminer si les patients atteints de NMO qui sont séronégatifs ont effectivement des anticorps dirigés contre l'AQP4.

Can J Neurol Sci. 2012; 39: 232-235

Neuromyelitis optica (NMO) is a severe idiopathic immunomediated inflammatory demyelinating and necrotizing disease that is characterized by transverse myelopathy and optic neuropathy. The exact etiology and mechanisms of NMO remain unknown. Serological and clinical evidence of B cell autoimmunity has been observed in a high proportion of patients, ${ }^{1}$ suggesting a prominent role for humoral mechanisms in the pathogenesis of NMO. Neuromyelitis optica lesions show a marked deposition of immunoglobulins and complement in a characteristic perivascular rosette pattern along the outer rim of thickened vessel walls ${ }^{2}$. A specific IgG autoantibody, NMO-IgG, selectively targeting aquaporin 4 (AQP4), which accumulates in the central nervous system (CNS) microvessels, pia, subpia, and Virchow-Robin space, has been confirmed by indirect immunofluorescence with a composite substrate of mouse tissue $^{3,4}$. According to this antibody, the new diagnostic criteria for NMO proposed by Wingerchuk et al facilitate its distinction from multiple sclerosis $(\mathrm{MS})^{5,6}$. In subsequent studies, analysis of pathological brain lesions in NMO patients revealed a pattern of vasculocentric immune complex deposition and AQP4 loss identical to that seen in NMO lesions, suggesting that AQP4 antibodies are related to NMO pathology 7,8 .

Although more than 15 different immunoassays for the detection of AQP4 antibodies in patients with NMO have been developed, only a proportion of patients (33-91\% among Western NMO cases and 41.7-91\% among Japanese opticospinal MS (OSMS) are positive for AQP4 antibodies in serum $^{3,9,10}$. In other words, the number of sero-negative NMO patients is not negligible.

From the Department of Neurology (YL, ZL, XH), The Third Affiliated Hospital of Sun Yat-Sen University; Department of Neurology (YL), Clinical College, The First Affiliated Hospital of Guangdong Pharmaceutical University, Guangzhou, Guangdong Province, People's Republic of China.

Received June 20, 2011. Final Revisions Submitted September 28, 2011. Correspondence to: Hu Xueqiang, Department of Neurology, The Third Affiliated Hospital of Sun Yat-Sen University, 600 Tianhe Road, Guangzhou 510630, Guangdong Province, People's Republic of China. 
In the present study, we collected cases of sero-positive and sero-negative NMO and compared their clinical and magnetic resonance imaging (MRI) features.

\section{Patients And Methods}

\section{Patients}

All the patients were consecutively admitted to the Multiple Sclerosis Centre at the Third Affiliated Hospital of Sun Yat-sen University, between August 2006 and March 2011. All were treated for more than four months in our hospital. No patients were receiving treatment with interferon-beta or immunosuppressants before the study, and no patients had received corticosteroid shock treatment in the previous month. Patient data were collected from the records retrospectively. We recruited 39 consecutive South Chinese Han people with NMO who met the criteria ${ }^{3}$. Informed consent was obtained from all patients for this study.

Data acquired from each admission record included age, sex, medication, number of demyelinating events, clinical characteristics of each relapse, and Expanded Disability Status Scale (EDSS) ${ }^{11}$ assessed at the most recent clinical examination.

\section{MRI scanning}

Brain and spinal MRI scans were performed on all patients using a GE 1.5 T MR imager scanner (General Electric, Milwaukee, WI). The slice thickness of the axial scans was 3-5 $\mathrm{mm}$. Conventional MRI protocols were used for all patients: T1 with and without gadolinium enhancement, (400/15.5 ms, TR/TE) and T2 (2500-3500/100 ms, TR/TE) for spinal cord MRI; T2 (4600-4640/97.8-102 ms, TR/TE), fluid attenuated inversion recovery (8800-/120 ms, TR/TE) for brain MRI.

\section{AQP4 antibody testing}

All the patients provided cerebrospinal fluid (CSF) and serum samples, which were stored at $-80^{\circ} \mathrm{C}$ in the central laboratory of the Third Affiliated Hospital of Sun Yat-sen University. The samples were obtained before treatment with glucocorticoids or immunosuppressive agents. AQP4 antibodies were determined using a cell-based assay on an AQP4-transfected cell line from a commercial BIOCHIP kit ${ }^{12,13}$ (EUROIMMUN AG, Lübeck, Germany).

\section{NMO-IgG testing}

To eliminate possible false-negative results, we repeated the NMO-IgG testing using indirect immunofluorescence on monkey substrate (cerebellum, stomach, and kidney). Briefly, serum $(1: 10)$ or CSF $(1: 1)$ was diluted in phosphate-buffered saline (PBS). The diluted sample was reacted with monkey cerebellum, stomach, and kidney sections on slides (EUROIMMUN AG) overnight at $4^{\circ} \mathrm{C}$. The slides were rinsed twice with PBS, before incubation with fluorescein-conjugated goat antibody for 30 minutes (min). Finally, the slides were rinsed with PBS and the fluorescent signal examined under a microscope(EUROIMMUN AG, Lübeck, Germany). To enhance the specificity for NMO-IgG, positivity was scored only if three absolute requirements were met: (1) IgG antibody selectively binds to CNS microvessels, pia, subpia, and Virchow-Robin space; (2) IgG antibody selectively binds to distal convoluted tubule and collecting duct of kidney; (3) IgG antibody selectively binds to parietal cells of the stomach.

\section{Statistical analysis}

All statistical analyses were performed using the Statistical Program for Social Sciences statistical software (version 11.0; SPSS, Inc., Chicago, IL). Differences in the proportions of seropositive and sero-negative patients were tested for significance by Fisher's exact test. All the other data in this study are presented as mean \pm SD and differences between sero-positive and sero-negative patients were analyzed by Student's t-test or Mann-Whitney U test. P-values $<0.05$ were considered significant.

\section{RESULTS}

We recruited 39 consecutive Chinese patients with NMO (3 men and 36 women; mean age 35.7 years, SD 13.4 years), whose main lesions were in the spinal cord and optic nerve, and who had been treated for more than four months in our hospital. The patients' demographic and clinical data are summarized in Table 1.

\section{AQP4 antibodies in serum and CSF}

Thirty NMO patients $(76.9 \%, 30 / 39)$, called sero-positive $\mathrm{NMO}$, were positive for serum AQP4 antibodies by the cellbased assay. The other nine NMO patients were sero-negative $(33.1 \%, 9 / 39)$, called "sero-negative" NMO here. Thirty-seven CSF samples $(94.9 \%, 37 / 39)$ were positive for AQP4 antibodies. Among these, seven $(77.8 \%, 7 / 9)$ were sero-negative (Table 2). Interestingly, the other two patients, who had no AQP4 antibodies in their serum or CSF by our cell-based assay, did have IgG antibodies in serum, which selectively targeted the CNS microvessels, pia, subpia, Virchow-Robin space, kidney or stomach, by indirect immunofluorescence with a composite substrate of monkey tissue.

\section{Clinical features of the 39 NMO patients}

According to the cell-based assay AQP4 antibody status, the patients were divided into two groups: sero-positive and seronegative NMO. We compared the clinical features between the two groups (Table 1). In sero-positive NMO patients $(n=30$, female $/$ male $=28 / 2$ ), the mean EDSS score was 5.98, the mean onset age was 35.2 years, and the mean duration was 47.73 months. In sero-negative NMO patients $(\mathrm{n}=9$, female $/$ male $=$ $7 / 2$ ), the EDSS and duration were 4.67 and 37.55 months, respectively, and the mean onset age was 37.5 years. The seropositive NMO patients had higher CSF AQP4 antibody titers than the sero-negative NMO patients $(P=0.001)$. There was no significant difference between the groups for any other factor, but there was a strong trend for sero-positive NMO patients to have a higher EDSS score $(\mathrm{P}=0.082)$.

\section{Discussion}

Serum AQP4 antibodies have been shown to be a highly specific and moderately-to-highly sensitive biomarker for NMO. This has been confirmed in many studies, and the presence of such antibodies is now among the diagnostic criteria for $\mathrm{NMO}^{5,6}$. 
Table 1: Patient demographic and clinical data

\begin{tabular}{|c|c|c|c|c|}
\hline & All & Sero-positive NMO & Sero-negative NMO & $P$ \\
\hline$n$ & 39 & 30 & 9 & - \\
\hline Onset age (y) & $35.74 \pm 13.14$ & $35.2 \pm 14.28$ & $37.5 \pm 8.69$ & 0.643 \\
\hline female/male & $12(36 / 3)$ & $14(28 / 2)$ & $3.5(7 / 2)$ & 0.223 \\
\hline duration (months) & $53.54 \pm 62.69$ & $47.73 \pm 52.86$ & $37.55 \pm 8.69$ & 0.375 \\
\hline EDSS & $5.60 \pm 1.92(2-8.5)$ & $5.98 \pm 1.88(2.5-8)$ & $4.67 \pm 2.08(2-8.5)$ & 0.082 \\
\hline \multicolumn{5}{|l|}{ Symptoms } \\
\hline sensory & $38 / 39(97.4 \%)$ & $29 / 30(96.7 \%)$ & $9 / 9(100 \%)$ & 1.0 \\
\hline motor & $33 / 39(84.6 \%)$ & $26 / 30(86.7 \%)$ & $7 / 9(77.8 \%)$ & 0.607 \\
\hline brainstem & $8 / 39(20.5 \%)$ & $7 / 30(23.3 \%)$ & $1 / 9(11.1 \%)$ & 0.653 \\
\hline visual & $39 / 39(100 \%)$ & $30 / 30(100 \%)$ & $9 / 9(100 \%)$ & 1 \\
\hline cerebellum & $0(0 / 39)$ & $0 / 30(0)$ & $0 / 9(0)$ & 1 \\
\hline cognitive & $0(0 / 39)$ & $0 / 30(0)$ & $0 / 9(0)$ & 1 \\
\hline sphincter & $20 / 39(51.5 \%)$ & $15 / 30(50 \%)$ & $5 / 9(55.6 \%)$ & 1 \\
\hline \multicolumn{5}{|l|}{ Brain MRI } \\
\hline MS-like lesions & $7.69 \%(3 / 39)$ & $2 / 30(6.7 \%)$ & $1 / 9(11.1 \%)$ & 0.556 \\
\hline Gad enhancing & $2.56 \%(1 / 39)$ & $0 / 30(0)$ & $1 / 9(11.1 \%)$ & 0.231 \\
\hline \multicolumn{5}{|l|}{ Spinal MRI } \\
\hline$\geq 3 \mathrm{Seg}$ & $94.87 \%(37 / 39)$ & $28 / 30(93.3 \%)$ & $9 / 9(100 \%)$ & 1.000 \\
\hline Gad enhancing & $33.3 \%(13 / 39)$ & $9 / 30(30 \%)$ & $4 / 9(44.4 \%)$ & 0.447 \\
\hline CSF protein $(\mathrm{g} / \mathrm{L})$ & $0.41 \pm 0.34$ & $0.41 \pm 0.33$ & $0.42 \pm 0.40$ & 0.882 \\
\hline Abnormal CSF protein $(n)$ & $38.9 \%(14 / 39)$ & $9 / 30(40 \%)$ & $5 / 9(55.6 \%)$ & 0.238 \\
\hline CSF cells $\left(\mathrm{no} . / \mathrm{mm}^{3}\right)$ & $10.87 \pm 14.05$ & $12.40 \pm 15.17$ & $5.78 \pm 8.09$ & 0.321 \\
\hline Abnormal CSF cells $(n)$ & $19 / 39(48.7 \%)$ & $15 / 30(50 \%)$ & $4 / 9(44.4 \%)$ & 1.000 \\
\hline IgG index & $1 / 39(2.56 \%)$ & $1 / 24(4.17 \%)$ & $0 / 9(0)$ & 1.000 \\
\hline CSF IgG level & $0.47 \pm 0.23$ & $0.49 \pm 0.12$ & $0.44 \pm 0.12$ & 0.393 \\
\hline CSF OCB & $3 / 39(7.69 \%)$ & $3 / 24(12.5 \%)$ & $0 / 9(0)$ & 1.000 \\
\hline CSF AQP4 antibody titers & $1: 2-1: 1280$ & $1: 10-1: 1280$ & $1: 2-1: 128$ & $<0.0001$ \\
\hline
\end{tabular}

NMO, neuromyelitis optica; EDSS, Expanded Disability Status Scale; MRI, magnetic resonance imaging; MS, multiple sclerosis; CSF, cerebrospinal fluid; OCB, oligoclonal bands; Gad, Gadolinium; seg, segment; n, number; IdG, immunoglobin G; y, years

A previous study suggested that the presence of AQP4 antibodies was 33-91\% sensitive (median 63\%) and $85-100 \%$ specific (median 99\%) for $\mathrm{NMO}^{9}$.

There are some discrepancies in the clinical features between Asian and Western serum antibody-positive NMO and serum antibody-negative NMO cases. In a French study, Marignier and colleagues reported that there was no difference between NMOIgG sero-positive and sero-negative NMO patients according to their clinical, CSF, and imaging features ${ }^{14}$. However, in the Japanese, AQP4 antibody-positive NMO/OSMS patients had a greater frequency of longitudinally extensive spinal cord or brain lesions than did anti-AQP4 antibody-negative NMO/OSMS patients ${ }^{9,15-17}$. These discrepancies may be accounted for by patient selection (NMO versus OSMS patients; different populations) and false-negative findings because of the low sensitivity of the assay. In the present study, to exclude the confounding influence of patient selection, all our patients were southern Han Chinese. The present findings indicate similar results to the French study.

Recently, Klawiter found that AQP4 antibodies were detectable in the CSF in three cases with negative serum antibodies ${ }^{19}$, implying that sero-negative AQP4 antibody NMO cases are not the same as "negative AQP4 antibody" cases. We also detected CSF antibodies in sero-negative patients. Furthermore, the two patients in whom we detected no AQP4 antibodies in either serum or CSF using the cell-based assay were indeed positive using the indirect immunofluorescence assay. This suggests that previously "negative" patients might be false-negatives because of the limits of assay, and that antiAQP4 antibodies may in fact be present in all NMO patients. It also indicates that it is important to re-test sero-negative NMO patients using a CSF sample or another assay. In other words, our 
Table 2: AQP4 antibody status in CSF and in serum

\begin{tabular}{cccc}
\hline & & \multicolumn{2}{c}{ AQP4 antibody status in CSF } \\
\cline { 3 - 4 } & & + & - \\
\hline AQP4 antibody status in & + & $30(76.92 \%)$ & 0 \\
serum & - & $7(17.95 \%)$ & $2(5.13 \%)$ \\
\hline
\end{tabular}

NMO, neuromyelitis optica; EDSS, Expanded Disability Status Scale; MRI, magnetic resonance imaging;

MS, multiple sclerosis; CSF, cerebrospinal fluid; OCB, oligoclonal bands

NMO patients had no obvious heterogeneity in terms of AQP4 antibody status. The reason that the sero-positive NMO cases had higher EDSS scores in the present study may be related to their high CSF AQP4 antibody titers. It also indicates intrathecal pathogenic effects of AQP4 antibodies ${ }^{20}$. The small sample size of sero-negative NMO cases is the major limiting factor of our study; significant results might be obtained using a larger sample size.

In conclusion, there was no obvious difference between the sero-positive and sero-negative NMO patients in our series of 39 cases. Repeating the test using a different assay or with a CSF sample is helpful to clarify whether sero-negative NMO patients do in fact carry AQP4 antibodies.

\section{ACKNOWLEDGMENTS}

This work was supported by funds from the 5010 Project of Sun Yat-Sen University and the Technology Project of Guangzhou City (No. 2060402). Part of the work was undertaken in the Pancreatic Disease Institute of GuangDong Pharmaceutical University.

\section{REFERENCES}

1. Hamnik SE, Hacein-Bey L, Biller J, Gruener G, Jay W. Neuromyelitis optica (NMO) antibody positivity in patients with transverse myelitis and no visual manifestations. Semin Ophthalmol. 2008;23:191-200.

2. Lucchinetti CF, Mandler RN, McGavern D, et al. Role for humoral mechanisms in the pathogenesis of Devic's neuromyelitis optica. Brain. 2002;125:1450-61.

3. Lennon VA, Wingerchuk DM, Kryzer TJ, et al. A serum autoantibody marker of neuromyelitis optica: distinction from multiple sclerosis. Lancet. 2004;364:2106-12.

4. Lennon VA, Kryzer TJ, Pittock SJ, Verkman AS, Hinson SR. IgG marker of optic-spinal multiple sclerosis binds to the aquaporin4 water channel. J Exp Med. 2005;202:473-7.

5. Cheng Q, Miao L, Zhang J, et al. Clinical features of patients with multiple sclerosis from a survey in Shanghai, China. Mult Scler. 2008;14:671-8.

6. Fazio R, Malosio ML, Lampasona V, et al. Antiacquaporin 4 antibodies detection by different techniques in neuromyelitis optica patients. Mult Scler. 2009;15:1153-63.
7. Jarius S, Wildemann B. AQP4 antibodies in neuromyelitis optica: diagnostic and pathogenetic relevance. Nat Rev Neurol. 2010;6: 383-92.

8. Jarius S, Paul F, Franciotta D, et al. Mechanisms of disease: aquaporin-4 antibodies in neuromyelitis optica. Nat Clin Pract Neurol. 2008;4:202-14.

9. Matsushita T, Isobe N, Matsuoka T, et al. Aquaporin-4 autoimmune syndrome and anti-aquaporin-4 antibody-negative opticospinal multiple sclerosis in Japanese. Mult Scler. 2009;15:834-47.

10. Matsushita $\mathrm{T}$, Isobe $\mathrm{N}$, Matsuoka $\mathrm{T}$, et al. Anti-aquaporin-4 antibody is involved in the pathogenesis of NMO: a study on antibody titre. Brain. 2007;130:1235-43.

11. Wingerchuk DM, Lennon VA, Pittock SJ, Lucchinetti CF, Weinshenker BG. Revised diagnostic criteria for neuromyelitis optica. Neurology. 2006;66:1485-9.

12. Kurtzke JF. Rating neurologic impairment in multiple sclerosis: an expanded disability status scale (EDSS). Neurology. 1983;33: 1444-52.

13. Jarius S, Franciotta D, Paul F, et al. Cerebrospinal fluid antibodies to aquaporin-4 in neuromyelitis optica and related disorders: frequency, origin, and diagnostic relevance. J Neuroinflammation. 2010;7:52

14. Li R, Qiu W, Lu Z, et al. Acute transverse myelitis in demyelinating diseases among the Chinese. J Neurol. 2011 [Epub ahead of print].

15. Marignier R, De Sèze J, Vukusic S, et al. NMO-IgG and Devic's neuromyelitis optica: a French experience. Mult Scler. 2008;14: 440-5.

16. Kanzaki M, Mochizuki H, Ogawa G, et al. Clinical features of opticospinal multiple sclerosis with anti-aquaporin 4 antibody. Eur Neurol. 2008;60:37-42.

17. Nakashima I, Fujihara K, Miyazawa I, et al. Clinical and MRI features of Japanese patients with multiple sclerosis positive for NMO-IgG. J Neurol Neurosurg Psychiatry. 2006;77:1073-5.

18. Matsuoka T, Matsushita T, Kawano Y, et al. Heterogeneity of aquaporin-4 autoimmunity and spinal cord lesions in multiple sclerosis in Japanese. Brain. 2007;130:1206-23.

19. Klawiter EC, Alvarez E 3rd, Xu J, et al. NMO-IgG detected in CSF in seronegative neuromyelitis optica. Neurology. 2009;72: 1101-3.

20. Bennett JL, Lam C, Kalluri SR, et al. Intrathecal pathogenic antiaquaporin-4 antibodies in early neuromyelitis optica. Ann Neurol. 2009; 66:617-29. 